Document downloaded from:

http://hdl.handle.net/10251/40595

This paper must be cited as:

Galiana Agullo, M.; Mas Tomas, MDLA.; Galvañ Llopis, V.; Lerma Elvira, C.; Conesa Tejada, S. (2012). METHODOLOGY OF THE VIRTUAL RECONSTRUCTION OF ARQUITECTONIC HERITAGE: AMBASSADOR VICH S PALACE IN VALENCIA. International Journal of Architectural Heritage. 1-10. doi:10.1080/15583058.2012.672623.

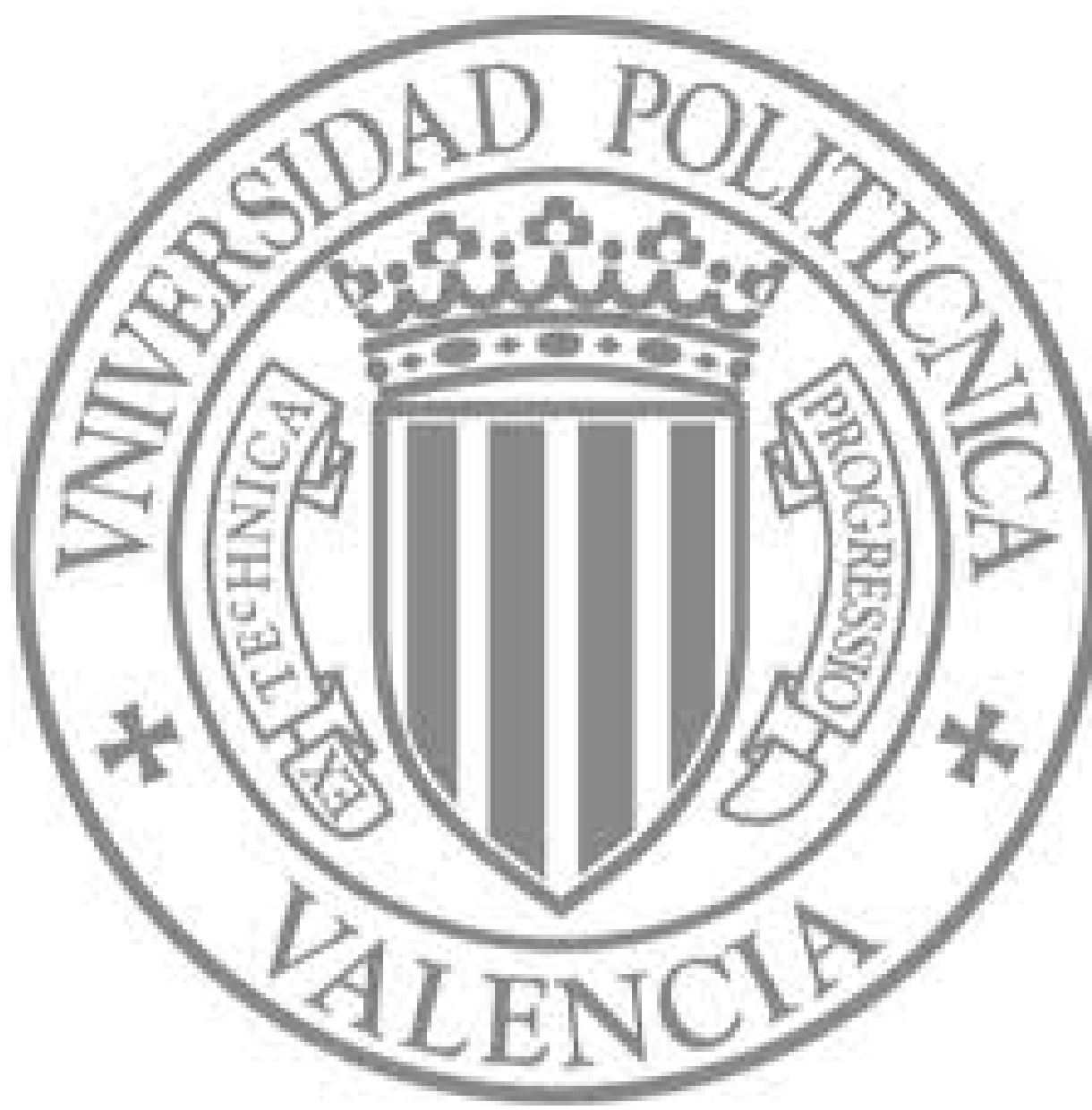

The final publication is available at

http://dx.doi.org/10.1080/15583058.2012.672623

Copyright Taylor \& Francis: STM, Behavioural Science and Public Health Titles 


\section{METHODOLOGY OF THE VIRTUAL RECONSTRUCTION OF ARQUITECTONIC HERITAGE: AMBASSADOR VICH'S PALACE IN VALENCIA}

\section{Authors}

Mercedes Galiana ${ }^{a}$, Ángeles Más ${ }^{b}$, Vicente Galvañ ${ }^{c}$, Carlos Lerma ${ }^{d}$ and Salvador Conesa ${ }^{\mathrm{e}}$.

Responsible author: Mercedes Galiana

Tel.: +34652830335

E-mail: mergalia@gmail.com

\section{Biography:}

${ }^{a}$ Architect. Master in Architectonic Heritage Conservation. Associated Lecturer in the Catholic University of San Antonio, Murcia, (Spain).

${ }^{b}$ Doctor of Architecture. Lecturer responsible for Construction of the Higher Technical School of Architecture of Valencia (Spain).

${ }^{\mathrm{c}}$ Professor of the Department of Construction Materials of the Higher Technical School of Architecture of Valencia (Spain).

${ }^{\mathrm{d}}$ Architect. Master in Architectonic Heritage Conservation. Assistant lecturer in the Higher Technical School of Architecture of Valencia (Spain).

${ }^{\mathrm{e}}$ Doctor of Fine Arts. Associated lecturer with the School of Fine Arts of Murcia (Spain). 


\section{ABSTRACT}

The 19th century was disastrous as far as the conservation of architectonic heritage is concerned. The awareness of the importance of preserving monuments that has prevailed since the end of the last century, was dazzlingly absent in the previous, leading both to the disappearance of representative heritage works and the plundering of many others.

The present study establishes the methodological bases to proceed with the virtual reconstruction of many disappeared architectures, representative of emblematic architectonic typologies. A method based on the combination of deduction and induction allows benchmarks to be created which signify a starting point, to which the key and specific elements of each building are later incorporated, from the data extracted from the conserved parts and the graphic, literary and archive documents. The result is the virtual recovery of the general outlines of the architecture: morphology of the plot, volumetry, exterior and interior façades and the functional layout.

The good results obtained in the study of the disappeared Ambassador Vich's palace, allow the methodology to be extended to the analysis of other similar examples, serving investigators as a tool to carry out an arduous task of deciphering a trail that is increasingly fading with the passing of time.

Key words: methodology of heritage recovery, Gothic and Renaissance architecture, disappeared architectures. 


\section{INTRODUCTION}

Ambassador Vich's palace in Valencia was one of the earliest and purest examples of Renaissance architecture in Spain. This building, which disappeared after being demolished in 1858, brought about the importation of the new style to the Peninsula, not just as a mere ornamental technique, but as a new way of understanding space, of composing and constructing its elements, as well as working its materials. Mr. Jerónimo Vich y Valterra, owner and developer of the same, was an influential politician in the Spain of the Catholic Kings, ambassador in Rome between 1507 and 1519, where he resided until the return to his hometown in 1521 . On his return, he would commission the ancient gothic family residence to be remodelled into a splendid Renaissance palace, more in keeping with the new architectonic trends that were widespread in that époque in Italy.

Both the architecture of this palace as that of many other contemporary examples of the city, which disappeared in great part in the mid-nineteenth century, should be read, not as a typology that is loyal to a determined artistic style, but as the result of the coexistence of Gothic and Renaissance, which, whilst sharing the features of typologies derived from a common origin, the domus vitruviana, they are clearly differentiated.

The virtual reconstruction methodology of these buildings should be based on a profound knowledge of these architectonic styles, establishing both the coincident and differentiating parameters, and the key elements of its functional, spatial and ornamental layout. We are using a scientific method, combining deduction and induction, which shows great effectiveness in achieving the established objectives. The deductive method allows the benchmarks to be set that serve as a starting point for the study, defining the fundamental parameters of both typologies. Next, we dissect them like a puzzle, incorporating through induction the particularities of the building under study, extracted from the data provided or translated both from the conserved parts of the building, and the planimetric, graphical, historical and archive 
documentation. The result allows the general outlines of the building being studied, to be reproduced in a fairly approximate way (ZONTA 2008).

\section{TYPOLOGICAL RECONSTRUCTION}

\subsection{Setting of benchmarks.}

We must establish which are the parameters that allow an architecture to be associated to a determined architectonic style. The fundamental aspects of palace typologies are:

\subsubsection{Urban situation and morphology of the plot.}

Both the old Valencian Gothic noble houses and the Roman Renaissance palaces, typologies that interweave in the palace under study, are large sized, single-family residential buildings. They have a relevant urban presence, comparable to large public buildings. They are usually found occupying entire blocks, due to their location on the new routes of the large Roman Renaissance roads, in the case of the Italians, or on wide plots of land obtained after the demolition of old Muslim houses, within the walled city, in the case of the Valencians, separated from each other by a small service alley denominated antuixà. Their dimension, together with the formal and material quality of the exterior façades, emphasize the importance of the proprietary families, differentiating their residences from the typical middle and lower-class houses, the Roman "house in strips" and the Valencian alberg.

\subsubsection{Functional layout: relation access-courtyard-stairs.}

Both typologies are based on the classic concept of domus vitruviana, the Gothical from the influence of Romanic architecture and the Renaissance from the return to the classical ideas of the Imperial Époque. They are buildings organised around a courtyard, a functional distribution centre of the house. The true palace residence is found on the main floor whereas the lower ground floor, entresol and attic are reserved for storage, for trading activities and for the servants' housing, respectively. The Roman Renaissance palaces differ from 
the Gothic ones by developing the ground floor, the attic disappearing as the sixteenth century advanced.

A lobby, which leads to the courtyard, is accessed from the main doorway. In Gothic palaces, the hallway serves as an element of communication with the lower levels, housing secondary access stairways to the lower ground floor and to the entresol. It usually occupies the first bay, although in the case of the large palaces, it is possible to find two adjacent bays. It is covered with a ceiling of wooden beams, with flat beam spacing or Valencian beam filler (Figure 1). In the Renaissance ones, this space is conceived as a corridor, covered with a barrel vault or a succession of ribbed vaults. It is devoid of added elements, with walls that are blocked, or open to the adjacent living rooms of the ground floor (Figure 2). Their main function is to communicate the access directly with the main courtyard.

The main difference between both styles is the layout, typology and courtyard-stairs relationship. Gothic palaces are characterised by the opening of the walls of the ground floor of the courtyard with large lowered arches, followed by a space covered with a flat, wooden-beam ceiling in the way of a porch. The stairs, L-shaped, start from one of the lateral supports, with the first section covered by the same, arranged perpendicularly to the façade, the long section of the $L$ running parallel to this, usually from the access wall to the courtyard from the hallway, or failing this, by its symmetrical one (Figure 1). Generally, this part remains uncovered, although on occasions, we can find an overhang at the height of the attic, creating a cover for the same. The courtyard-stair relationship is direct, its outline recognisable throughout the whole run.

In Renaissance palaces, this relationship is understood in a completely different way. It is a gated courtyard, with at least one gallery parallel to the façade on the landing of the access corridor, which can be extended to the opposite side, to the adjacent sides and even to the whole perimeter, in palaces of greatest importance, with all the cases being organised on the basis of a strict symmetry (CASTEX 1990). The first gallery is responsible for communicating with the nucleus of vertical traffic, a crossed stairway situated in a closed space adjacent 
to the courtyard, with sections that are perpendicular to the façade (Figure 2). The visual relationship of the courtyard-stairs is completely lost. The walls remain free from added elements, allowing the main living quarters of the palace to be tipped into this interior space, that gains importance in regards to the preceding typology.

\subsubsection{Typology of exterior and interior façades.}

The exterior façade layout is a constant in these palaces. The walls are divided on the ground floor, with gaps on two levels to light the lower ground floor and the entresol, a main floor of great height, with large windows corresponding to the palace's main living rooms and attic, with smaller spaces. In Gothic palaces, a crenelated profile defence tower stands on one of the corners (Figure 3), a section of medieval tradition that disappears in Renaissance architecture, promoting symmetry and regulating the cornice line (Figure 4).

The doorway usually occupies a central position in the façade, with exceptional cases in which it is moved to one side. A semi-circular arch materialises as the opening, created with fine and long stone keystones, coplanar with the wall, in Gothic doorways (Figure 3) and with small stone keystones, strongly embossed and with jagged profiles, in the Italian ones. In these latter ones, moulded arches, framed with columns elevated on pedestals and finished with classical decorative entablatures (Figure 4), are just as usual. Both formats stand out because of their great height, exceeding the level reached by the ground floor windows and emphasising in this way the presence and verticality of the access.

The Gothic façades are characterised by the arrangement of the window spaces without any compositive order, which on occasions are arranged in an apparent random fashion, with variable distances between them, losing the vertical alignment between the gaps of the different levels (Figure 3). On the contrary, the Renaissance ones present a rigorous symmetry in their composition, marked by the vertical axis of the doorway, where the central 
keystones are placed, with the same number of gaps appearing at either side, distributed uniformly (Figure 4).

The two levels of spaces of the ground floor appear perfectly differentiated in the Valencian palaces, the lower ones, rectangular oblong in shape and with sloped sides, arranged at floor level, and the upper ones, almost square, perceptibly predominating the vertical dimension, arranged at a greater height and separated from the first. Whilst in the Italian ones, these two windows are unified in a double composition. The lower ground level spaces, larger in size than the previous, practically square, join with the spaces of the ground floor, which are clearly vertically rectangular.

The large windows of the main floor are decorated with lobulated arches on fine columns in the way of mullions in Gothic architecture, whilst in Renaissance architecture, they are framed with moulds and are finished with entablatures or triangular or segmental pediments.

The geometry and decoration of the second floor's spaces, which are smaller in size, are much simpler and more austere. In the Valencian palaces, they are substituted on many occasions by a gallery of semi-circular arches on columns, traditionally Aragonese, which run from one side of the façade to the other, interrupted on the tower's section. The façade is finished on its upper level with powerful wooden eaves of marked projection in the Valencian palaces and with moulded cornices in the Italian ones.

The layout of interior walls is more differentiated in both typologies. In Gothic palaces, the ground floor is occupied by the colonnades and main stairway, the spaces of the lower ground floor and entresol disappearing. On the main floor, there are large windows similar in shape to those of the exterior façades, but smaller in size, the coexistence on the same façade of diverse typologies and sizes being usual, as well as their combination with gated galleries that run along part of some wall section. On the attic level, the same type of space typology is repeated as in the exterior elevations. 
Renaissance palaces are characterised by reproducing, as far as is possible, the layout of the exterior walls in the interior ones. It is possible that on the ground floor and main floor, some of the walls are altered by the presence of arcaded galleries, arranged in this case, with perfect symmetry, in harmony with the rest of the composition.

\subsubsection{Materiality and ornament.}

In Medieval ages, well-off families cared for the materiality of the exterior façades of their urban residences, created with blocks of stone originating from the area's quarries, a sign of the proprietors' power and lineage. The interior walls were of poorer quality and their decoration more austere, the living rooms were covered with simple wooden partitions. The large exterior windows were reduced on the inside to a small window with the typical festejadores.

In Renaissance palaces, the interior courtyard becomes the most cared for space of the building, for which the best and most novel compositions are conceived and where the highest quality noble materials are used, authentic works of art. The main living rooms open up to the same through large windows and are covered with rich cofferings with complex, geometric patterns.

Whilst the Medieval palaces are characterised by their extrovert character, investing all their resources in their exterior image, in the Renaissance, an introversion is produced that focuses attention towards the interior, more specifically towards the main courtyard.

The ornamentation in Gothic palaces is reduced practically to the windows of the main floor, where the lintels stand out, created with lobulated arches over mullions, with an upper flame-shaped cleft. It is most common to find two-arches compositions, but occasionally, large windows can appear with three partitions. The bases and capitals of the columns are usually worked with bas-relief carvings. The entresol windows are decorated with moulds on the jambs and splayed arches, with support bases on the sill. Likewise, the attic gallery's arches have a moulded section. On the inside, the stairway stands out, 
made entirely from stone and decorated with jagged moulding that reproduces the interior steps on the surface of the solid handrail.

The ornamental richness of Renaissance palaces is infinitely superior, with numerous elements carved in marble and Italian limestone, especially in the interior courtyards, decorated with high-relief rich carvings on capitals, arches, jambs, pediments and cornices.

In general, we can emphasise the more mimetic character of the ornaments in Gothic architecture, where elements are repeated in different palaces, with identical examples of one motif being found on numerous occasions (LÓPEZ 1995). On the contrary, the ornaments of Renaissance architecture are more exclusive, and two identical compositions are not found, not even in projects of the same architect, artists who tend to differentiate themselves from one another, whilst still sharing a common style, corresponding with the humanistic philosophy that accompanied the Renaissance.

\subsection{Analysis of the conserved parts of the building.}

In regards to the conserved elements, we should establish a clear difference between those that survived the building's demolition and those recovered recently.

\subsubsection{Conserved elements.}

In September of 1857 the complaint was filed for No. 12 Ambassador Vich Square, for the bad state of its façade on the Corredores Street (Municipal Archive of Valencia, $1^{\text {st }}$ September 1857), an event that triggered a series of inspections that ended with the order to demolish the building in December of the same year (Municipal Archive of Valencia, $20^{\text {th }}$ December 1857), which was carried out in the following spring (Municipal Archive of Valencia, $26^{\text {th }}$ April 1858). The Fine Arts Academy of San Carlos, who knew of the imminent disappearance of the architectonic ensemble started proceedings to safeguard 
the objects that it considered to be of interest (Archive of the Royal Academy of Fine Arts of San Carlos, Board of $3^{\text {rd }}$ January 1858), moving the courtyard's marbles and the coffering of the most relevant living rooms, two months prior to the palace's demolition (Archive of the Royal Academy of Fine Arts of San Carlos, Board of $6^{\text {th }}$ February 1859).

After a century and a half during which many different, isolated incidences with the marbles occurred, more or less fortunate, since 2006 we can again contemplate the architectonic ensemble of the Renaissance courtyard, reconstructed in a unifying act in the Museum of Fine Arts of San Pío $\checkmark$ in Valencia (BENITO 2000). This intervention by the museum, independently of the controversy surrounding the moving of some of the pieces already installed in the dependencies of other significant buildings of the city (VILA 2001 y ESTEBAN 2001), has relevant and clarifying virtues of the knowledge of the palace's architecture. It allows the exact dimensions of the central courtyard's ground plan to be known, perceptibly rectangular, 7,83 $\mathrm{m} \times 10,63 \mathrm{~m}$ (Figure 5). It has been possible to reliably corroborate the compositive layout of the façades, created with the white Carrara marble pieces (Figure 6), known so far by two illustrative drawings conserved in the archives of the Academy of Fine Arts of San Carlos, of 1801 (TRAMOYERES 1908). Its scale and proportions can also be observed from three points of view, ground floor, main floor and attic, materialised by multifunctional open rooms, created around the courtyard, currently closed to the public (Figure 7), recovering not only the surroundings, but the integral concept of the Vitruvian vaulted courtyard that characterises Renaissance courtyards.

\subsubsection{Archaeological fragments.}

After the demolition in 1999 of one of the nineteenth-century buildings that replaced part of the old footprint of the Vich house, archaeological excavations were carried out in which a large number of decorative and architectonic elements appeared that belonged to the palace. 
Five belts of the building's foundation were found, one facing north-south and four east-west (MARIMÓN 2001) (Figure 8). This discovery allowed the determination of the correct and exact situation of the palace in relation to the current planimetry.

\subsection{Planimetric analysis.}

The evolutionary study of historical plans allows the general data to be known, both of the building's geometry and the morphology of the plot. The doubts that arise from the different representations provided by the different plans are clarified by the evidence that the conserved parts provide, by the data extracted from graphical, literary and archive documents, or by the characteristics intrinsic to the typology determined by the studied benchmarks.

\subsubsection{Urban situation and morphology of the plot.}

The city of Valencia has two planimetries of great representative value, key in the study of its heritage buildings. The first of these, titled Valentia Edetanorum/ aliis Contestanorum, vulgo Del Cid./ Ichnographice Delineata, was prepared between 1701 and 1704 by Father Tomás Vicente Tosca. Recently restored (GAVARA 2003), it is one of the cartographic jewels of Valencian heritage, due to the degree of detail and precision reached by its perspective representation of the city. The second, titled Valentia Edetanorum vulgo Del Cid, Delineata a Dre. Thoma Uincentio Tosca Congr. Oratorij Presbytero, is an illustration done by José Fortea in 1738, inspired by Tosca's plan (HERRERA 1985). Although less famous than his predecessor, he intentionally corrects some inaccuracies made by the canon.

Thanks to these plans, we obtain the first knowledge of the plot (Figure 9). The palace was situated between the Corredores Street and Mascons Street, next to the Pelota Square, in the old University quarter. It occupied a whole block, with three of its façades facing the main streets and the fourth separated from the adjoining building by a narrow antuixà. 
At the beginning of the $19^{\text {th }}$ century this alley began to be privatised, with walls being raised at both ends, that delimited the outline of a new block composed by both buildings, the southern limit established on the same Santa Eulalia Street (Figure 10). Likewise, Corredores Street became known as Moratín Street, Mascons Street as Ambassador Vich and the Pelota Square as the Mariano Benlliure Square, names that still stand today.

Three years after the demolition of the Palace, the new buildings already occupied the eastern half of the small street (Figure 11), which would soon disappear completely, with no trace of it being found by the end of the $19^{\text {th }}$ century. The block maintained its morphology until the end of the $20^{\text {th }}$ century, a moment in which a dent is produced in the old alignment due to the setback produced by the rebuilding of one of the plots of land of the current Ambassador Vich street.

\subsubsection{Functional layout: access-courtyard-stairway relationship.}

The analysis of these plans allows us to extract key data for the interpretation of the functional layout of the building. Both represent a freestanding building, with a large central courtyard, somewhat displaced towards the east, perceptibly rectangular in shape and with two smaller rear courtyards, on the south façade, adjacent to the service alley. Two accesses to the building are shown, one of them situated in a central position in regards to the façade to the Ambassador Vich Street, eastern façade and another situated on an axis with the tower's section on the northern façade, facing the Square on the corner (Figure 9). The plans exchange the layout of the main access, so that the functional layout derived from both interpretations comes into conflict, as the position of the same determines its relationship with the courtyard and the stairway, elements of spatial organisation.

Tosca's plan situates the main access on the corner of the square. This location would determine a tangential relationship with the courtyard, as it would remain facing one of the galleries of the ground floor, whilst meaning a direct encounter with the start of the stairway, situated always in a space adjacent to 
the courtyard, necessarily in the northern section, that would house the building's main living rooms.

Fortea's plan situates the doorway more prominently in the middle of the façade facing the Ambassador Vich Street. This turn establishes a new functional layout, with the access facing one of the axes of the courtyard, apparently the longitudinal one, and a more gradual sequence of spaces between the public and private part, accessed by an intermediate point of the gallery and through this to the stairway, with which visual connection is now lost.

\subsubsection{Typology of the exterior and interior façades.}

The typology of façade that emerges from the interpretation of both plans is practically coincident (Figure 9). The northern side is formed by four levels of windows, corresponding to the interior spaces of the lower ground floor, entresol, main floor and attic. The watchtower is situated on the left corner, which is elevated one level above the rest. The access is arranged on the tower's axis of symmetry, followed by five or six equidistant openings. Arranged at floor level, small spaces are found that correspond to the lower ground level and over these, the windows of the entresol, greater in dimension. Large windows open onto the main floor on an axis with the lower ones. The one that corresponds with the tower's section seems lower than the rest and the horizontal alignment is lost, acquiring the same presence as the two upper spaces, probably with identical sections. On the attic level the spaces are smaller and rectangular oblong in shape, aligned with those of the lower floors.

The façade is characterised by the symmetry of its composition, broken only by the presence of the tower on the north corner. In a central position, the other access to the building stands out, on whose axis no other space is situated. It is flanked by two columns of windows on both sides, where the openings of the entresol and main floor stand out. Now, the spaces of the lower ground level are not distinguished, apparently blocked up, nor is the attic, possibly hidden by the projection of the eave. The wall face corresponding to 
the tower section appears to be blocked, blurring its presence on the façade, lessening its importance within the ensemble.

The interior façades, partially hidden by the situation of the perspective point of view, is traced with simple lines. Again, the compositive layout represented in both plans comes into conflict. Tosca arranges the characteristic composition in serliana of the transversal elevations of the courtyard on the ground floor of the north façade, whilst Fortea represents in that same elevation, the arcade of three openings that shape the longitudinal gallery, repeating the $90^{\circ}$ turn in their respective representations. This would mean situating the longitudinal axis of the courtyard with north-south orientation, in the first case, and east-west in the second. Likewise, the first interpretation disassociates the position of the doorway in regards to the axis, whilst in the other way, the access is aligned with it.

\subsection{Graphical analysis.}

Amongst the conserved graphical documents the illustration of the main doorway of the Cecilio Pizarro palace stands out (Archive of the Royal Academy of Fine Arts of San Carlos, Bundle 149, Sheet no. 145) (TRAMOYERES 1908) (Figure 12). It has great representative value, given that it reveals the composition of the Renaissance style of the doorway, now disappeared, whilst also showing the relationship between the building's access and the interior courtyard.

The doorway is aligned with the longitudinal axis of the courtyard, as the interior walls parallel to the façade, materialised on the ground floor with the characteristic composition of arch between lintels, corresponding to the transversal sides. This information clarifies the doubt in regards to the correspondence of the Renaissance doorway with the central access of the façade of Ambassador Vich Street. Additionally, it shows the arrangement of the first gallery parallel to the façade, occupying the first bay of the building, situated behind the exterior wall. 


\subsection{Documentary analysis.}

Among the literary and archive documents, we highlight those that reveal data related to the architecture of the palace.

Firstly, we encounter another clarifying comment of the controversy generated around the building's accesses. Vicente Boix, director of the newspaper "La Tribuna", that was published for years in the printers "Agencia de España", whose headquarters were installed in the palace towards 1840 (BENITO 2000), relates in a description of the urban environment of the building, that the house belonging to the Ambassador had two doors, one to which he refers as the "old" one, situated on Ambassador Vich Street, and another "modern" one that faced the square (BOIX 1979).

Firstly we understand that the meaning of "old" architecture, can be understood as that which descends from or makes reference to classical Greek and Roman shapes. On the other hand, we are certain that the Renaissance doorway maintained its original composition, without being altered by the superposition of elements of other styles, since the Pizarro illustration belongs to those years prior to the demolition of the palace. This, added to the total ignorance of the morphology of the other access and analysing the development of other doorways from other currently preserved Valencian Gothic palaces, that underwent modifications corresponding to their adaptation to architectonic styles of later époques, again leads us to believe that the main access of the building should be situated in a central position of the façade of Ambassador Vich Street.

Another relevant document in regards to the morphology of the plot and its size is found in the demolition record of the palace (Municipal Archive, City Police, File no. 92, Box 85, 1857, note from $9^{\text {th }}$ July 1860 . In the proprietor's handwriting, we can read the petition to the City Council to declare the building as a ruin, the demolition order and the spans (Valencian unit of measurement of $23 \mathrm{~cm}$ ), that the new buildings had to enter in accordance with the new 
alignment of the plot. This data allows us to reproduce the old footprint of the palace, determining its exact location referred to the current planning.

\section{RESULTS}

Having determined the benchmarks and compiled and analysed the conserved data of the palace being studied, we proceed to re-compose the general lines of its architecture.

\subsection{Urban situation and morphology of the plot.}

The "Topographical plan of the City of Valencia of El Cid" produced by Ramón María Ximénez between 1857 and 1860, years in which the Vich palace was demolished (Figure 11), is key in determining the location of the small street that limited the plot of land on the southern side. In the year of publication of this plan part of the plot had already been rebuilt, a fact which was evident with the disappearance of the north-eastern part corresponding to the small street, now occupied by the new buildings, which shows that the same buildings determined the limit of the old small street. Precisely, the demolition of said building in 1999 lead to the archaeological excavation in which five of the old moved footings of the palace's foundation appeared. As such, we can proceed and insert said foundations and the old footprint of the small street within the boundaries of the current block (Figure 13).

The morphology detached from the representation of the palace on the plans of Tosca and Fortea (Figure 9), determines the necessary correspondence of some of the bays limited by these foundations, with those corresponding to one of the sides of the Renaissance courtyard that used to occupy this position. Knowing the dimensions of the ground plan of the courtyard after its installation in San Pío (Figure 5), and knowing the spans between the different belts (Figure 8), we can proceed with the fitting and superposition of the same, verifying the coincidence of one of the bays with the transversal sides (Figure 14). In this way, the arrangement of the courtyard's longitudinal axis is confirmed as having an east-west direction. 
On the other hand, the north-south belt should correspond to one of the façades parallel to the Ambassador Vich Street. In previous studies, the possibility was presented that it belonged to the exterior wall of the palace, which would mean a setback with regards to the current alignment of the road (MARIMÓN 2001). We can refute this hypothesis after analysing the proprietor's letter which made reference to "the spans under the new line, the new house had to be entered from each one of the three façades" (City Police, File No. 92, Box 85,1857 , note from $9^{\text {th }}$ July 1860). As such we can corroborate that the new alignment was setback in regards to the original, so that the foundation of the exterior façade's wall should be situated under the new surface, agreeing at the same time, with the historical tendency towards the widening of urban streets in the historical quarter of the city. In this way, the north-south belt would correspond to the wall of the interior courtyard, establishing in this way the exact position of the courtyard, an element of functional organisation, within the plot (Figure 14).

By incorporating the spans setback in the $19^{\text {th }}$ century to the current alignment, we obtain the perimeter belonging to the old footprint of the palace (Figure 15).

\subsection{Functional layout: relationship access-courtyard-stairway.}

The geometric reconstruction of the plot provides us with a trapezoidal ground plan of around $1200 \mathrm{~m}^{2}$ in area, with average dimensions of approximately $36 \mathrm{~m}$ east-west and $29 \mathrm{~m}$ north-south. Analysing the openings delimited by the ground plan of the courtyard and the outline of the plot, as well as the volumes represented in the historical plans, we can establish the layout of the different bays that define the building ensemble and through these, interpret the functional layout.

This analysis again confronts the two studied historical plans. Tosca's plan represents a north section of great height, finished with a sloped gable roof draining onto the public street, delimited to the north by the section of the tower, 
that gains one level in height and on the opposite corner by the volume facing Moratin Street, with which it has no type of continuity. The east belt is divided at roof level, differentiating the part corresponding with the interior courtyard, towards which it drains its water, from the rest of the building whose gable slopes again towards the exterior. Two bays are clearly differentiated on the western belt, one adjacent to the courtyard, its roof facing towards the interior and another exterior, materialised by a lower section, as translated from the shadow cast that appears in the join between its gables (Figure 16).

Fortea again introduces some significant changes in the representation of this volumetry. He regulates the roof plans of the north and east bodies, with continuous gables sloped towards the exterior. The eastern bay loses continuity with the eaves of the interior courtyard, which maintain the height of the cornice and ridge between them, with a constant width of its bays. The section exterior to Moratin Street is now represented with a large sized gable, showing the great strength of its thickness, reaching a greater height than that of adjacent bodies, producing an encounter with the interior gable through a vertical plane of wall. The intersection between the volumes of the northeast corner remains unsolved, probably because of the complex representation of this join in the free perspective of the drawing (Figure 17).

We proceed to analyse these inconsistencies, raising a hypothesis of volumetric reconstruction of the palace, based on the benchmarks of contemporary palace typologies.

The volumetry of the Vich palace was not substantially modified during its adaptation to the new style, so that the general outlines of the building maintain the guidelines of Valencian Gothic palace constructions. In these buildings, the exterior sections maintain the height of the eave and the slope of the roof plans, spilling water towards the public road, perceptibly reaching the same height as the ridge as it maintains the width of the different bays. The interior sections repeat the same layout, on occasions reaching a lesser ridge height due to the reduction of the openings of the same, joining with the exterior ones through a vertical wall (SOLER 1996). 
Under these assumptions, the eave height of the three exterior façades of the palace would remain constant, disregarding the interruption on the northeast corner. Likewise, the equal slope of the roof gables would explain the distortion of the join with the corner, since the greater thickness of the west bay determines the greater height reached by its ridge, having a vertical plane on the intersection with the interior gable's ridges and the north section (Figure 18).

The proposed hypothesis resolves the volumetry of the exterior sections of the palace and the joining with the northeast corner, but the possible existence of other volumes, corresponding to the interior bays of the north and east belts remains to be resolved. If we suppose the layout of one sole bay, the volumetry contradicts one of the documents that was key to the recovery of the Renaissance courtyard, the illustration of José Forné from 1801 (Figure 19). In it, the elevation-section of the courtyard through its transversal axis is represented, showing the interior east elevation and the section of the adjacent spaces, corresponding to the north and south galleries. These lateral sections appear to be finished with sloped covered paths, draining towards the interior of the courtyard, the eave height and gable slope staying constant, the same as the exterior volumes. As the north belt has only one bay, the joining of the exterior gable with this wall would be produced at a greater height, breaking the symmetry of the courtyard in regards to its longitudinal axis.

Knowing the dimensions derived from the virtual reproduction of the plot over the current planimetry, the layout of the interior façade of the courtyard and the width of the perimeter gallery, we superimpose these elements and a thickness of over $4 \mathrm{~m}$ remains, up to the exterior boundary of the north belt, which allows us to think of the possible existence of two bays configuring this volume. This hypothesis reconciles the diverse representations of the palace, not contradicting the historical plans, as these volumes were hidden by the viewpoint chosen in the perspective.

The logic of this layout leads us to try and move it to the eastern belt. On this occasion, the layout of the width corresponding to the courtyard's lower 
gallery is practically placed on the road, so that by adding the thickness of the wall, we reach the plot's limit. As such in this case we dismiss the existence of a second bay, a conclusion that agrees with the known graphical documentation (Figure 12), that determines the layout of the first section of the vaulted gallery behind the wall of the façade, involves the loss of symmetry in regards to the transversal axis of the courtyard and determines a thickness of reduced dimensions in the north belt (Figure 18).

This information could be explained by the organisation of the original Gothic palace. The space occupied by the transversal gallery, behind the wall would correspond to the building's hall, which through a large segmental arch, would open onto the central distribution courtyard, where traditionally an Lshaped stairway would be located, that would run on two of the courtyard's galleries until reaching and providing access to the building's main floor. It is common for this stairway to have one of its sections crossing the courtyard's access wall, as occurs in several of the currently conserved Gothic palaces (Figure 1). It is likely that the main section of the stairs ran along the eastern gallery of the courtyard, starting with a small step of the colonnade situated on the southern bay. In this way a small overhang could exist at the level of the attic, providing said stairway with a cover, in such a way that it disappeared on moving the location of the same to an interior space after the remodelling of the building in the Renaissance style. This stairway layout would motivate the existence of a second roof panel, spilling waters towards the interior of the courtyard, unifying the roofs floor plan and justifying at the same time, the reduced dimension of said bay (Figure 20).

This floor plan layout agrees with the existence of the two accesses to the Gothic palace and its functional justifications. The main doorway, situated in a central position on the façade of the Ambassador Vich Street, would communicate with the building's hallway, where the access stairs to the rooms of the lower ground floor and entresol would be situated, and through them to the interior courtyard, centre of distribution and communication with the main floor, the residence of the proprietor. The second access on the corner could be related to the rooms of the entresol of the northern section, customarily used as 
estudi, where the proprietor would dedicate himself to his professional activities, providing in this way, an independent entrance to the private residence.

The remodelling of the building in the Renaissance style would involve substantial changes in the levels of the ground floor and main floor, as well as in the typology of the courtyard and its relationship with the accesses and the main stairs. The hallway and the porches would be eliminated, substituted by a vaulted gallery surrounding the ground floor, which would mean the transformation of many living rooms of the lower ground floor and entresol. The floor plan of the courtyard would remain completely free, reducing the eastern bay by the disappearance of the Gothic stairs. The nucleus of vertical traffic would now be arranged in a closed interior space, adjacent to the courtyard's gallery, probably in the building's north bay, the landing being at the same point as its predecessor for functional reasons. It would be the typical centralised crossed stairway, with stringers perpendicular to the main façade, which would start from a prolongation of the courtyard's lower gallery, specifically the eastern gallery, a space formerly reserved for the secondary access lobby, situated on the tower section (Figure 21).

This layout involves the loss of some of the substantial elements of Renaissance palace architecture, such as the existence of the vaulted passageway that communicates the access with the interior courtyard. Even so, the essential aspects of this typology prevail, which are introduced for the first time in the Valencian architectonic environment.

\subsection{Typology of exterior and interior façades.}

To recover the original configuration of the exterior façades is relatively simple on the basis of the compositive scheme provided by the studied historical plans. In them, the eastern and northern elevations are redesigned and whose criteria can be extended to the west façade, on which we know no access existed. 
Knowing the Gothic architecture tendency towards the repetition of decorative compositions and elements and the Renaissance architecture to establish compositive and aesthetic connections between the exterior and interior façades, we can imagine general lines of the exterior image of the building.

We also have some tangible examples with which we can establish direct connections, such is the case of the palace of the Generalidad of Valencia, somewhat later than the Vich house, on which it was inspired when elaborating the composition of the windows of the main floor, using its original composition, a hybrid between the Gothic and Renaissance style (Figure 22).

In this way we are able to reproduce the façades corresponding both to the original Gothic palace (Figure 23), and the remodelled Renaissance palace (Figure 24).

\subsection{Virtual reconstruction of the palace.}

The synthesis of all the study allows us to recover, albeit virtually, the essence of one of the most relevant architectures of the Valencia architectonic heritage, a century and a half after its disappearance (Figure 25).

\section{CONCLUSIONS}

The investigative scientific methodology used in the study of the disappeared Ambassador Vich palace, combining deduction and induction, has shown great effectiveness in favour of the virtual reconstruction of the architectonic heritage that has disappeared (Lourenoa, 2011).

The deductive method has allowed us to reach conclusions of a specific architecture, on the basis of general data extracted from the benchmarks of each one of the typologies involved in the study, constituted by the examples that have reached our times of many contemporary buildings. 
At the same time, the inductive method has allowed the specific and concrete peculiarities of this building to be introduced in these typological benchmarks, allowing the clarification of many of the controversies generated in the global interpretation of its architecture.

The good result of this methodology allow it to be extended to the study of many lost architectural examples in different styles, serving as a tool for investigators to carry out an arduous task of deciphering a trail that is increasingly fading with the passing of time.

\section{ACKNOWLEDGEMENTS}

To the Museum of Prehistory and Archaeology of Valencia and to the Museum of Fine Arts San Pío V of Valencia.

\section{REFERENCES}

Benito, F. 2000 The courtyard of the Ambassador Vich palace. Elements for its recovery (in Spanish).

Boix V. 1979. Historical and Topographic Valencia Vol. I, 261 (in Spanish).

Castez, J. 1990. Renaissance, Baroque and Classicism. History of Architecture, 1420-1720, 136 (in Italian).

Esteban, J. 2001. Installation of the courtyard of Ambassador Vich in the exconvent of Carmen (Valencia). Loggia, 12, 26-43.(in Spanish).

Gavara, J.J. 2003. Plan of Valencia of Tomás Vicente Tosca (1704). (El plano de Valencia de Tomás Vicente Tosca (1704)) (in Spanish).

Gavara, J. J. 2006. The Ambassador Vich. The Man and his times 112-115. (L'Ambaixador Vich. L'Home i el seu temps. 112-115) (in Valencian). 
Herrera, J. M. et aliis. 1985. Cartographic History of the City of Valencia. 17041910. (in Spanish).

Marimón, F. 2001. The archaeological excavation of the plot of the Vich palace. The Courtyard of the Ambassador Vich Palace: an installation for debate. Days of the Territorial College of Architects of Valencia. Unpublished (in Spanish).

Morrisha, S.W. and Laefera, D.F. 2010. Web-Enabling of Architectural Heritage Inventories. International Journal of Architectural Heritage, 4, 16-37.

López, M. C. 1995. Gothic palaces of the city of Valencia. Their study and cataloguing. Graphical example. Doctoral thesis. Unpublished (in Spanish).

Lotz, W. 1997. Architecture in Italy 1500 - 1600. 35-37 (in Italian).

Lourenoa, P.B. et aliis. 2011. A Document Management System for the Conservation of Cultural Heritage Buildings. International Journal of Architectural Heritage, 5, 101-121.

Soler, R. 2001. The d'En Bou Palace of Valencia. Superimposed architectures. Loggia, 3, 60-73 (in Spanish).

Vila, S. 2001. The recovery of the courtyard of Ambssador Vich Palace (Valencia). Loggia, 12, 44-51 (in Spanish).

Tramoyeres, L. 1908. Italian Renaissance in Valencia. Courtyard of Ambassador Vich. Spanish Culture, 517-524 (in Spanish).

Zonta, D. et aliis. 2008. Managing the Historical Heritage Using Distributed Technologies. International Journal of Architectural Heritage, 2, 200-225. 


\section{FOOTNOTES}

Figure 1: Main stairs and access situation layouts in the Gothic palaces of En Bou, Escrivá and Boil, Marquises de Scala y Almirante (LÓPEZ 1995).

Figure 2: Palma Baldassini Palace, Rome, $16^{\text {th }}$ century (LOTZ 1997), Ossoli Soderini palace, Rome, $16^{\text {th }}$ century and Valle o del Búfalo palace, Rome, $16^{\text {th }}$ century (CASTEX 1990).

Figure 3: Main façade of the Palace of Benicarló, Valencia, $15^{\text {th }}$ century.

Figure 4: Main façade of the Palma Baldassini palace, Rome, $16^{\text {th }}$ century (LOTZ 1997).

Figure 5: Ground plan of the Renaissance courtyard of the Fine Arts Museum San Pío V in Valencia.

Figure 6: Transversal and longitudinal elevation of the courtyard of the palace of Ambassador Vich.

Figure 7: Image of the courtyard from the multifunctional room of the main floor.

Figure 8: Layout arrangement of the archaeological remains of the Vich palace foundations.

Figure 9: Vich Palace on the Tosca (1704) and Fortea (1738) plans.

Figure 10: Geometric plan of the city of Valencia called Del Cid, Francisco Ferrer, 1828

Figure 11: Topographical plan of the city of Valencia of El Cid, Ramón María Ximénez, 1861.

Figure 12: Illustration of the main doorway of the Vich palace, Cecilio Pizarro, 1560. Archive of the Royal Academy of Fine Arts of San Carlos. Bundle 149, Sheet $n^{\circ} 145$.

Figure 13: Situation plan of the foundation belts of the Vich Palace and of the back service alley on the Zoning Map of Valencia, 2008.

Figure 14: Superimposition of the courtyard floor plan over the archaeological remains of the foundations of the Vich palace.

Figure 15: Reproduction of the old footprint of the Ambassador Vich palace on the Zoning Map of Valencia, 2008. 
Figure 16: Volumetric layout of the Ambassador Vich palace, translated from the geometry represented on Father Tosca's plan, 1704.

Figure 17: Volumetric layout of the Ambassador Vich palace, translated from the geometry represented on Fortea's plan, 1738.

Figure 18: Volumetric hypothesis of Ambassador Vich's palace.

Figure 19: Photograph of the illustration of the transversal of the courtyard of the Ambassador Vich Palace, done by José Fornés in 1801. Archive of the Royal Academy of Fine Arts of San Carlos, Bundle 154, Sheet no 105.

Figure 20: Layout of the Gothic courtyard with possible arrangement of the stairway leant against the interior wall of the building's hallway. Hypothetical elevation of said front (SECTION A-A').

Figure 21: Hypothetical functional layout of the Renaissance palace.

Figure 22: Windows of the main floor of the turret of the Palace of the Generalidad in Valencia.

Figure 23: Hypothesis of elevations of the pre-existing Gothic palace.

Figure 24: Hypothesis of elevations of the Renaissance palace.

Figure 25: Computer graphics of the hypothetical reconstruction of the Ambassador Vich palace in Valencia. 